\title{
PENGARUH TENURE DEWAN KOMISARIS, INDEPENDENSI DEWAN KOMISARIS, KEPEMILIKAN INSTITUSIONAL TERHADAP TAX AVOIDANCE
}

\author{
Hilda Mary, SE.MM, Nila Pratiwi, SHI, MA, Syndica Dela Agtisen \\ Universitas Putra Indonesia YPTK Padang, Indonesia \\ E-mail: hildamary@upiyptk.ac.id
}

\begin{abstract}
This study aims to determine the factors that affect earnings management in corporate reporting on companies listed on the Indonesia Stock Exchange in 2014-2016. The variables used in this study are auditor switching, big-four KAP, audit committee independence, firm size, and profitability. The research sample is 70 companies listed in Indonesia Stock Exchange (BEI) 2014-2016 periods. The sampling technique is random sampling.

The result shows that KAP Big-Four, Komite Audit Indipendence and firm size have a positive effect on earnings management. While, auditor switching and profitability have no impact on earnings management.
\end{abstract}

Primary Key: earnings management, switching auditor, big-four KAP, audit committee

\section{Pendahuluan}

Laporan keuangan merupakan sarana penyimpanan informasi keuangan yang digunakan sebagai penghubung antara perusahaan dengan pihak-pihak diluar perusahaan yang bekepentingan. Salah satu tujuan pelaporan keuangan adalah memberikan informasi keuangan yang dapat menunjukan prestasi perusahaan dalam menghasilkan laba. Kinerja manajemen perusahaan dapat dinilai dari besar laba dalam laporan keuangan sehingga informasi laba merupakan informasi penting dalam pengambilan keputusan oleh investor dan kreditor (Rahdal, 2017).

Laporan tahunan memberikan informasi mengenai kondisi keuangan dan informasi non keuangan kepada pemegang saham, kreditur, stakeholders dan calon stakeholders lainnya. Informasi kondisi keuangan merupakan salah satu informasi yang di butuhkan pihak eksternal dalam menilai kinerja suatu perusahaan melalui laporan keuangan perusahaan. Laporan keuangan yang diperoleh pihak ekseternal adalah bentuk pertanggung jawaban dari hasil akhir proses akuntansi, untuk menimbang kinerja manajemen perusahaan. Salah satu pengukuran kinerja manajemen perusahaan adalah melalui analisis informasi laba yang ada pada laporan keuangan. Oleh karena itu, informasi laba ini sering menjadi target tindakan oportunis manajemen untuk memaksimumkan kepuasannya (Purnama, 2017).

Dalam laporan keuangan, laba merupakan indikator penting untuk menilai kondisi suatu perusahaan. Informasi yang terdapat dalam laba menjadi unsur utama dalam laporan keuangan dan sangat dibutuhkan bagi pihak-pihak tertentu. Dalam prosesnya, terkadang pihak pengurus pengelola perusahaan memiliki motivasi dan kepentingan yang berbeda yang cendrung bertantangan dengan kepentingan dan motivasi pemegang saham dan stakeholders lainnya. Sehingga, laporan keuangan disalah gunakan dengan melakukan investasi dalam proses penyusunan laporan keuangan dengan cara meratakan, menaikan dan menurunkan laba sehingga dapat mempengaruhi jumlah laba yang akan dilaporkan. Hal ini biasanya disebut dengan istilah manajemen laba (earnings managemen). Manajemen laba sendiri muncul karena adanya konflik kepentingan antara pemilik perusahaan dengan manajemen (Kurniawan, 2018).

Earnings manajemen pada saat para manajer menggunakan judgment dalam pelaporan keuangan dan dalam penataan transaksi untuk mengubah laporan keuangan yang bertujuan untuk 
menyesatkan para stakeholders tentang kinerja keuangan perusahaan atau untuk mempengaruhi hasil yang tergantung pada angka-angka akuntansi yang dilaporkan. Pada saat melakukan diteksi atas ada atau tidaknya earnings manajemen pada sebuah peusahaan seharusnya dikaitkan dengan kinerja keuangan, dan versi modifikasi. Perusahaan melakukan manajemen laba untuk mencegah terjadinya penurunan earnings dan kerugian (Widyaningsih, 2017).

Auditor switching merupakan pergantian auditor yang dilakukan oleh perusahaan klien itu sendiri. Pergantian auditor secara sukarela (voluntary auditor switching) terjadi apabila klien mengganti auditornya tanpa ada peraturan yang mewajibkan klien untuk melakukan pergantian auditor. Voluntary auditor switching ini menimbulkan pertanyaan bagi banyak pihak akan alasan perusahaan mengganti auditor tanpa peraturan yang mengharuskan perpindahan auditor. Di sisi lain, Nasser et al. (2006) menyatakan pergantian auditor secara sukarela akan cendrung mengakibatkan peningkatan fee audit (Faradila dan Yahya, 2016).

Auditor switching merupakan perpindahan auditor atau pergantian auditor yang dilakukan oleh perusahaan klien akibat adanya kewajiban rotasi auditor. Pada dasarnya pergantian auditor merupakan salah satu cara dalam meningkatkan independensi auditor dan kualitas audit. Pergantian auditor bisa terjadi secara sukarela atau secara wajib. jika pergantian auditor (auditor switching) dilakukan secara sukarela, maka faktor-faktor penyebab terjadinya dapat berasal dari klien dan juga bisa dari sisi auditor. Jika pergantiannya dilakukan secara wajib seperti yang terjdi di Indonesia karena sudah ada peraturan tertentu yang mewajibkan pergantian auditor (auditor switching) sesuai dengan peraturan yang telah ditetapkan (Werdhaningtias, 2017).

Dalam banyak kasus hilangnya independensi auditor dikarenakan telah mengaudit sebuah perusahaan dalam waktu lama, maka Menteri Keuangan menyempurnakan kembali peraturan lama dalam keputusan Menteri Keuangan No.17/PMK01/2008 tentang jasa akuntan publik. Dalam peraturan tersebut tecatat bahwa pergantian auditor terjadi setelah kantor akuntan publik (KAP) memberikan jasa auditnya selama 6 (enam) tahun berturut-turut, dan bagi auditor publik yang memberikan jasa auditnya selama 3 (tahun) berturut-turut. penugasan jasa audit oleh KAP maupun auditor publik tersebut dapat dilakukan kembali setelah periode satu tahun diaudit oleh kap atau auditor lainnya. Tidak ada pertanyaan terkait hal itu karena bersifat wajib dan memaksa, dan ada beberapa perusahaan melakukan hal tersebut dikarenakan hanya ingin mematuhi peraturan yang sedang berlaku dinegara dimana perusahaan beroperasional (Sinarto dan Wenny, 2018).

Kantor Akuntan Publik (KAP) adalah suatu bentuk oraganisasi akuntan publik yang memperoleh izin sesuai dengan peraturan perundang-undangan, yang berusaha dibidang pemberian jasa profesional dalam praktek akuntan publik. Ukuran akuntan publik merupakan besar kecilnya suatu KAP yang tergolong dari dua jenis, yaitu KAP yang berafiliasi dengan KAP big four dan KAP yang non big four. Ukuran KAP dapat dikatakan besar apabila KAP tersebut yang berfiliasi dengan big four mempunyai cabang dan jumlah kliennya besar serta memiliki tenaga professional diatas 25 orang (Panjaitan, 2017)

KAP big four umumnya memiliki sumber daya yang lebih besar dibandingkan dengan KAP non big four sehingga merka dapat menyelesaikan pekerjaan auditnya relatif lebih efektif dan efisien (Rustiana,2007). Namun demikian, dengan adanya semakin ketatnya persaingan dalam lingkungan KAP, maka KAP non big four berusaha untuk mengaudit laporan keuangan klien dengan efektif dan efisien yang ditunjukan bahwa dalam penelitian mereka selisih audit report lag pada perusahaan yang diaudit oleh KAP big four dan Kap non big four hanya dengan 5 hari dengan selisih standar deviasi 3 hari. KAP non big four berusaha untuk memberika jasa audit kepada kliennya dengan kualitas yang sama baiknya dengan KAP big four (Panjaitan, 2017).

Tindakan manajemen laba tersebut dapat diminimumkan melalui suatu mekanisme monitoring yang bertujuan untuk menyelaraskan (alignment) berbagai kepentingan yang disebut corporate governance. Corporate governance merupakan konsep yang diajukan demi peningkatan kinerja perusahaan malalui supervisi atau monitoring kinerja manajemen dan menjamin akuntabilitas manajemen terhadap stakeholder dengan mendasarkan pada kerangka peraturan. Salah satu faktor yang mempengaruhi manajemen laba ialah kurangnya atau buruknya penerapan corporate governance pada suatu perusahaan. Ketika pemegang saham dan manajer memiliki kepentingan 
yang berbeda, corporate governance memiliki rule of game yang harus diikuti oleh setiap pihak tersebut (Oktari, 2018).

Corporate Governance merupakan konsep yang di ajukan demi peningkatan kinerja perusahaan melalui supervisi atau monitoring kinerja manajemen terhadap stakeholder dengan mendasarkan kepada kerangka peraturan. Konsep corporate governance diajukan demi tercapainya pengelola perusahaan yang transparan bagi semua pengguna laporan keuangan. Bila konsep ini diterapkan dengan baik maka diharapkan pertumbuhan ekonomi akan terus menanjak seiring dengan transparansi perusahaan yang semakin baik dan nantinya menguntungkan banyak pihak. Sistem corporate governance memberi perlindungan efektif bagi pemegang saham dan kreditor sehingga mereka yakin akan memperoleh return atas investasinya dengan benar. Corporate governance juga membatu menciptakan lingkungan kondusif demi terciptanya pertumbuhan yang efisien dan sustainable di sektor korporat. Corporate governance dapat didefenisikan sebagai susunan aturan yang menentukan hubungan antara pemegang saham, manajer, kreditor, pemerintah, karyawan, dan stakeholder internal dan eksternal yang lain sesuai dengan hak dan tanggung jawabnya (Marismiati, 2017).

Komite audit adalah komite yang dibentuk oleh dewan komisaris untuk melakukan tugas pengawasan pengelolaan perusahaan. Keberadaan komite audit sangat penting bagi pengelolaan perusahaan. Komite audit merupakan komponen baru dalam sistem pengendalian perusahaan. Selain itu komite audit dianggap sebagai penghubung antara pemegang saham dan dewan komisaris dengan pihak manajemen dalam menangani masalah pengendalian (Marismiati, 2017).

\section{Tinjauan Literatur}

\subsection{Paragraph}

\subsubsection{Auditor Switching}

Wijaya dan Remini (2015) Pergantian auditor merupakan ada atau tidak pergantian auditor yang dilakukan perusahaan klien. Variabel pergantian auditor diukur menggunakan variabel dummy, apabila tidak terjadi pergantian diberi tanda 0 dan diberi tanda 1 apabila terjadi pergantian (Nesser, et al., 2006).

H1 : Diduga Auditor switching berpengaruh terhadap manajemen laba pada perusahaan manufaktur yang terdaftar di BEI.

\subsubsection{KAP Big-Four}

Wijaya dan Resmini (2015), Hasil penelitian (Nasser et al., 2006; Damayanti \& Sudarma, 2007; Wijayanti, 2011) membuktikan bahwa ukuran KAP berpengaruh signifikan terhadap auditor switching. Sementara itu penelitian (Sinason et al., 2001) tidak berhasil membuktikan adanya pengaruh ukuran KAP terhadap auditor switching.

H2 : Diduga KAP big-four berpengaruh terhadap manajemen laba pada perusahaan manufaktur yang terdaftar di BEI.

\subsubsection{Ukuran Komite Audit}

Ukuran komite audit adalah berapa jumlah anggota darikomite audit (Junaedi dan Farina, 2017). Menurut KNKG (2006) jumlah anggota komite audit harus disesuaikan dengan kompleksitas perusahaan dengan tetap memperhatikan efektivitas dan pengambilan keputusan.Ukuran komite audit yang tepatakan memungkinkan anggota untuk menggunakan pengalaman dan keahlian mereka bagikepentingan terbaik stakeholder.

H3 : Diduga ukuran komite audit berpengaruh terhadap Manajemen Laba pada perusahaan manufaktur yang terdaftar di BEI. 


\subsubsection{Manajemen Laba}

Purnama (2017) Manajemen laba (earning management) adalah upaya manajer perusahaan untuk mengintervensi atau mempengaruhi informasi dalam laporan keuangan dengan tujuan untuk mengelabui stakeholder yang ingin mengetahui kinerja dan kondisi perusahaan.

\section{Metodologi Penelitian}

\subsection{Populasi dan Sampel}

Populasi merupakan wilayah generalisasi yang terdiri atas obyek atau subyek yang mempunyai kualitas dan karakteristik tertentu yang ditetapkan oleh peneliti untuk dipelajari dan kemudian ditarik kesimpulannya. Populasi yang akan diamati dalam penelitian ini adalah seluruh Manajemen Laba yang terdaftar di BEI. Pada Bursa Efek Indonesia (BEI) terdapat berbagai jenis Manajemen Laba yang dihitung berdasarkan kriteria masing-masing selama periode tahun 2012-2016. Pemilihan sampel dilakukan dengan teknik simple random sampling, dimana sampel yang diambil secara acak. Jumlah sampel penelitian ini berjumlah 70 perusahaan manufaktur yang terdaftar di BEI pada tahun 2012-2016.

\subsection{Pengukuran Variabel}

Manajemen Laba adalah potensi penggunaan manajemen akrual dengan tujuan memperoleh keuntungan pribadi (Riahi \& Belkaoui, 2011 : 201). Dechow et al. (dalam Ujiyantho dan Pramuka, 2007 : 11) menyebutkan bahwa penggunaan discretionary accruals sebagai proksi manajemen laba dihitung dengan menggunakan Modified Jones Model karena model ini dianggap lebih baik di antara model lain untuk mengukur manajemen laba.

$$
\mathrm{TAC}=\mathrm{Nit}-\mathrm{CFOit}
$$

Auditor Switching dalam diukur menggunakan variabel dummy. apabila perusahaan klien melakukan pergantian auditor maka diberikan nilai 1, dan apabila perusahaan tidak melakukan pergantian auditor maka diberikan nilai 0 .

Excluded group merupakan kelompok yang tidak termasuk dalam kategori yaitu kantor akuntan publik Non Big Four, sedangkan included group merupakan kelompok yang termasuk dalam kategori yaitu kantor akuntan publik Big Four. Variabel dummy adalah variabel yang berukuran kategori dengan memberi kode 0 (nol) untuk kelompok yang disebut dengan excluded group dan memberi kode 1 (satu) untuk kelompok yang disebut dengan included group (Ghozali,2005)

Komite audit (KA) merupakan komite yang dibentuk oleh dewan komisaris untuk mengawasi pengelola perusahaan. Komite audit ini juga berfungsi untuk memberikan pandangan mengenai masalah yang berhubungan dengan kebijakan keuangan, akuntansi, dan pengendalian internal. Komite audit ini harus terdiri dari individu-individu yang mandiri dan tidak terlibat dengan tugas sehari-hari dari manajemen yang mengelola perusahaan, dan mempunyai pengalaman agar lebih adil dan tidak memihak serta objektif dalam menangani suatu masalah.

Diukur menggunakan rumus :

$$
K M=\frac{\text { jumlah anggota komite audit independen }}{\text { jumlah } \text { komite audit }}
$$

Menurut Harahap (2007 :23) pengukuran ukuran perusahaan adalah: "Ukuran perusahaan diukur dengan logaritma natural (Ln) dari rata-rata total aktiva (total asset) perusahaan. Penggunaan total 
aktiva berdasarkan pertimbangan bahwa total aktiva mencerminkan ukuran perusahaan dan diduga mempengaruhi ketepatan waktu".

$$
\text { Firm's size }=\log (\text { total aset })
$$

Return On Assets merupakan bagian dari analisis rasio profitabilitas. Return On Asset merupakan rasio antara laba bersih yang berbanding terbalik dengan keseluruhan aktiva untuk menghasilkan laba. Rasio ini menunjukan berapa besar laba bersih yang diperoleh perusahaan diukur dari nilai aktivanya, Kasmir (2013).

$$
R O A=\frac{\text { Laba Bersih Setelah Pajak }}{\text { Total Asset }}
$$

Table 1: Operasional dan Pengukuran Variabel

\begin{tabular}{|c|c|}
\hline Variabel & Indicator \\
\hline Manajemen Laba & $T A C=$ Nit - CFOit \\
\hline Auditor Switching & Variabel dummy \\
\hline KAP Big Four & Variabel dummy \\
\hline $\begin{array}{c}\text { Mekanisme corporate } \\
\text { governance }\end{array}$ & $K M=\frac{\text { JUMLAH ANGGOTA AUDIT DARI LUAR PERUSAHAAN }}{\text { JUMLAH SELURUH ANGGOTA KOMITE AUDIT }}$ \\
\hline $\begin{array}{c}\text { Ukuran Perusahaan } \\
\text { Profitabilitas }\end{array}$ & Firm's size $=\log$ (total aset) \\
\hline
\end{tabular}

\section{Hasil dan Pembahasan}

\subsection{Hasil Analisis Deskriptif}

Statistik deskriftif adalah statistik yang digunakan untuk menganalisis data dengan cara mendeskripsikan atau menggambarkan data yang telah terkumpul sebagaimana adanya tanpa bermaksud mebuat kesimpulan yang berlaku untuk umum atau generalisasi (Sugiyono, 2014). Pengukuran yang digunakan dalam penelitian ini adalah Mean, standar deviasi, maximum dan minimum.

Table 2: Operasional dan Pengukuran Variabel

Descriptive Statistics

\begin{tabular}{lrrrrr}
\hline & N & Minimum & Maximum & Mean & \multicolumn{1}{c}{ Std. Deviation } \\
\hline LOG_ML & 134 & 0,78 & 3,55 & 2,61 & 0,49 \\
AS & 210 & 0,00 & 1,00 & 0,10 & 0,30 \\
KAP & 210 & 0,00 & 1,00 & 0,92 & 0,26 \\
KA & 210 & 0,25 & 1,00 & 0,35 & 0,13 \\
SIZE & 210 & 8,94 & 18,45 & 14,51 & 1,73 \\
ROA & 210 & $-0,99$ & 0,99 & 0,22 & 0,46 \\
Valid N (listwise) & 134 & & & & \\
\hline
\end{tabular}


Variabel Manajemen Laba yang terjadi rata-ratanya adalah sebesar 2,61 dengan standar deviasiasi 0,49 , nilai maksimum sebesar 3,55 dan nilai minimum sebesar 0,78. Variabel Auditor Switching yang terjadi rata-ratanya adalah sebesar 0,10 dengan standar deviasi 0,30, nilai maksimum sebesar 1,00 dan nilai minimum sebesar 0,00 . Variabel KAP Big-Four yang terjadi rata-ratanya adalah sebesar 0,92 dengan standar deviasi 0,26, nilai maksimum sebesar 1,00 dan nilai minimum sebesar 0,00. Variabel Komite Audit yang terjadi rata-ratanya adalah sebesar 0,35 dengan standar deviasi 0,13 , nilai maksimum 1,00 sebesar dan nilai minimum sebesar 0,25. Variabel Ukuran Perusahaan yang terjadi rata-ratanya adalah sebesar 14,51 dengan standar deviasi 1,73 , nilai maksimum sebesar 18,45 dan nilai minimum sebesar 8,94. Variabel Profitabilitas yang terjadi rata-ratanya adalah sebesar 0,22 dengan standar deviasi 0,46, nilai maksimum sebesar 0,99 dan nilai minimum sebesar $-0,99$.

\subsection{Hasil Uji Asumsi Klasik}

\subsubsection{Uji Normalitas}

Uji normalitas digunakan untuk mendeteksi apakah model regresi yang dirumuskan serta variabelvariabel yang digunakan dalam penelitian ini dapat terdistribusi normal atau tidak. Model regresi dikatakan baik apabila memiliki data yang dapat terdistribusi normal. Uji normalitas ini dapat diketahui dengan dua cara analisis, yaitu analisis grafik dan uji statistik One-Sample KolmogorovSmirnov test.. Berikut tabel uji normalitas dengan One-Sample Kolmogorov- Smirnov test:

Table 3: Hasil Uji Normallitas

One-Sample Kolmogorov-Smirnov Test

\begin{tabular}{llr}
\hline & & $\begin{array}{c}\text { Unstandardized } \\
\text { Residual }\end{array}$ \\
\hline $\mathrm{N}$ & Mean & 134 \\
Normal Parameters & & 0,000 \\
& Std. Deviation & 0,468 \\
& Absolute & 0,088 \\
Most Extreme Differences & Positive & 0,060 \\
& Negative & $-0,088$ \\
Kolmogorov-Smirnov Z & & 1,014 \\
Asymp. Sig. (2-tailed) & & 0,255 \\
\hline
\end{tabular}

Uji Normalitas data menggunakan alat Uji Kolmogorov SminovZ, dapat dilihat bahwa nilai signifikansi (Asymp.Sig2-tailed) sebesar 0,255. Karena signifikansi lebih dari 0,05 $(0,255>0,05)$, maka nilai residual tersebut lebih normal. Hal ini menunjukkan bahwa data yang diambil terdistribusi normal.

\subsubsection{Uji Multikoliniaritas}

Uji Multikolinearitas dilakukan untuk mengetahui apakah ada korelasi antar variabel bebas (independen). Untuk pengujian ini digunakan fasilitas uji Variance Factor (VIF) yang terdapat dalam program SPSS. Analisis regresi berganda dapat dilanjutkan apabila nilai VIF-nya kurang dari 10 dan nilai tolerance-nya di atas 0,1 . 
Table 4: Hasil Uji Multikoliniaritas Coefficients $^{\mathrm{a}}$

\begin{tabular}{llrrrrr}
\hline Model & & \multicolumn{2}{c}{$\begin{array}{c}\text { Unstandardized } \\
\text { Coefficients }\end{array}$} & $\begin{array}{c}\text { Standardized } \\
\text { Coefficients }\end{array}$ & \multicolumn{2}{c}{ Collinearity Statistics } \\
\cline { 3 - 7 } & & \multicolumn{1}{c}{ B } & Std. Error & Beta & Tolerance & VIF \\
\hline \multirow{2}{*}{ (Constant) } & 3,149 & 0,381 & & & \\
1 & AS & $-0,044$ & 0,164 & $-0,026$ & 0,776 & 1,289 \\
& KAP & 0,387 & 0,142 & 0,233 & 0,964 & 1,037 \\
& KA & $-0,858$ & 0,511 & $-0,160$ & 0,776 & 1,288 \\
& SIZE & $-0,042$ & 0,023 & $-0,160$ & 0,970 & 1,031 \\
& ROA & 0,127 & 0,089 & 0,123 & 0,944 & 1,060 \\
\hline
\end{tabular}

Nilai VIF pada sampel tidak ada yang melebihi 10 dan nilai tolerance tidak ada yang kurang dari 0,10. Hal ini berarti bahwa hasil nilai menunjukan tidak adanya masalah multikoliniaritas yang serius, sehingga dapat disimpulkan bahwa tidak terdapat gejala multikoliniaritas antar variabel bebas dan model ini layak digunakan dalam regresi analisis regresi berganda.

\subsubsection{Uji Heteroskedastisitas}

Uji heteroskedastisitas digunakan untuk menguji dalam model regresi terjadi perbedaan varian dari residual satu pengamatan kepengamatan lain. Apabila varian dari residual satu pengamatan kepengamatan lain tetap, maka disebut homoskedastisitas dan apabila berbeda disebut heteroskedastisitas. Model regresi dikatakan baik apabila terjadi homoskedastisitas atau dengan kata lain tidak terjadi heteroskedastisitas. Uji heteroskedastisitas dapat dianalisis dengan melihat grafik scatterplot, dengan dasar analisisnya sebagai berikut (Ghozali, 2011)

Table 5: Hasil Uji Heteroskedastisitas

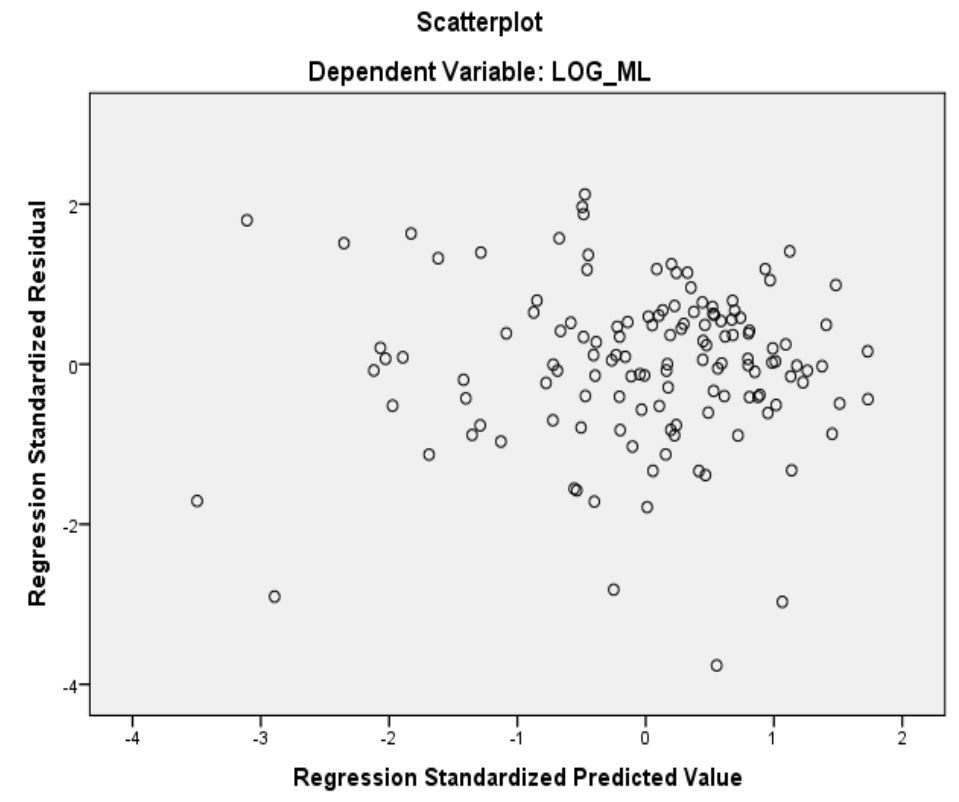

Titik-titik menyebar secara acak dan tidak membentuk suatu pola tertentu, serta tersebar di atas dan di bawah angka 0 pada sumbu Y. Ini berati tidak terjadi heteroskedastisitas pada model regresi. Sehingga model regresi ini dapat digunakan untuk menganalisis pengaruh pengaruh auditor switching, KAP big-four, komite audit terhadap manajemen laba. 


\subsubsection{Uji Autokorelasi}

Autokorelasi adalah korelasi atau hubungan yang terjadi antara anggota-anggota dari serangkaian pengamatan yang tersusun dalam rangkaian waktu (data time series) maupun tersusun dalam rangkaian ruang atau disebut data cross sectional. Salah satu pengujian yang umum digunakan untuk mengetahui adanya autokorelasi adalah uji statistik Durbin Watson. Hasil autokorelasi dapat dilihat dari tabel berikut.

Table 6: Hasil Uji Autokorelasi

\begin{tabular}{lrrrrr}
\multicolumn{6}{c}{ Model Summaryb } \\
\hline Model & R & R Square & $\begin{array}{c}\text { Adjusted R } \\
\text { Square }\end{array}$ & $\begin{array}{c}\text { Std. Error of the } \\
\text { Estimate }\end{array}$ & Durbin-Watson \\
\hline 1 & $0,315^{\mathrm{a}}$ & 0,099 & 0,064 & 0,47768 & 1,365 \\
\hline
\end{tabular}

Statistik D-W sebesar 1,365. Angka ini terletak diantara -2 dan +2 , dari pengamatan ini dapat disimpulkan bahwa tidak terjadi autokorelasi positif maupun autokorelasi negatif.

\subsection{Analisis Regresi Linier Berganda}

Uji estimasi linear berganda dengan menggunakan SPSS 21 dapat dilihat pada tabel dibawah ini:

Table 7: Hasil Analisis Regresi Berganda

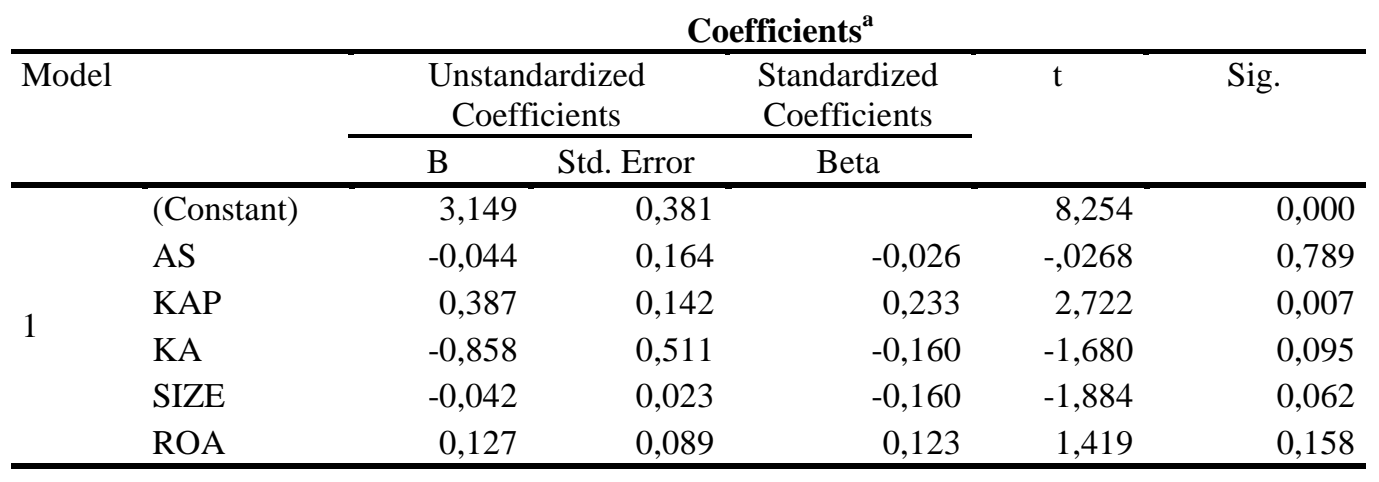

Berdasarkan tabel diatas maka dapat dilihat persamaan regresinya yaitu:

$$
Y=3,149-0,044 X 1+0,387 X 2-0,858 X 3-0,042 X 4+0,127 X 5
$$

Dari persamaan regresi berganda di atas dapat disimpulkan bahwa :

a. Konstanta diperoleh sebesar 3,149 hali ini berarti bahwa jika variabel Auditor Switching, KAP Big-Four, Komite Audit, Ukuran Perusahaan dan profitabilitas adalah 0, maka besarnya manajemen laba adalah sebesar konstanta 3,149.

b. Nilai koefisien regresi variabel Auditor Switching sebesar -0,044. Hal ini menandakan bahwa setiap kenaikan satu satuan auditor switching akan mengakibatkan penurunan nilai pada manajemen labayaitu sebesar $-0,44$ dengan asumsi variabel independen dan variabel kontrol lainnya tetap.

c. Nilai koefisien regresi variabel KAP Big-Four sebesar 0,387. Hal ini menandakan bahwa setiap peningkatan KAP big-four satu satuan akan mengakibatkan peningkatan pada manajemen laba sebesar 0,387 dengan asumsi variabel independen nilainya tetap. 
d. Nilai koefisien regresi Komite Audit sebesar -0,858. Hal ini menandakan bahwa setiap kenaikan komite audit satu satuan akan mengakibatkan penurunan pada manajemen laba sebesar $-0,858$ dengan asumsi variabel independen nilainya tetap.

e. Nilai koefisien regresi variabel Ukuran Perusahaan sebesar -0,042 Hal ini menandakan bahwa setiap kenaikan ukuran perusahaan satu satuan akan mengakibatkan penurunan pada manajemen laba sebesar $-0,042$ dengan asumsi variabel independen nilainya tetap.

f. Nilai koefisien regresi variabel Pofitabilitas sebesar 0,127. Hal ini menandakan bahwa setiap peningkatan profitabilitas satu satuan akan mengakibatkan penurunan pada manajemen laba sebesar 0,127 dengan asumsi variabel indenpenden nilainya tetap.

\section{Uji Koefisien Regresi Parsial (Uji t)}

a. Pengaruh Auditor Switching terhadap Manajemen Laba.

Pengaruh auditor switching terhadap manajemen laba dimana variabel auditor switching diketahui mempunyai koefisien negatif dan tidak signifikan terhadap manajemen laba karena besar regresinya $-0,044$ dan signifikan 0,789 (lebih besar dari 0,05). Hal ini mengindikasikan bahwa auditor switching tidak berpengaruh terhadap manajemen laba.

b. Pengaruh KAP BigFour terhadap Manajemen Laba

Pengaruh KAP Big-Four terhadap Manajemen Laba dimana variabel KAP Big-Four diketahui mempunyai koefisien positif dan signifikan terhadap manajemen laba karena besar regresinya 0,387 dan signifikan 0,007 (lebih kecil dari 0,05). Hal ini mengindikasikan bahwa KAP Big-Four berpengaruh positif terhadap manajemen laba.

c. Pengaruh Mekanisme Corporate Governance (Komite audit) terhadap Manajemen Laba

Pengaruh Komite Audit terhadap manajemen laba dimana variabel Komite Audit diketahui mempunyai koefisien negatif dan signifikan terhadap manajemen laba karena besar regresinya $-0,858$ dan tidak signifikan 0,095 (lebih kecil dari 0,10). Hal ini mengindikasikan bahwa Komite Audit berpengaruh positif terhadap manajemen laba.

\section{d. Pengaruh Ukuran Perusahaan terhadap Manajemen Laba}

Pengaruh ukuran perusahaan terhadap manajemen laba dimana variabel ukuran perusahaan diketahui mempunyai koefisien negatif dan signifikan terhadap manajemen laba karena besar regresinya -0,042 dan signifikan 0,062 (lebih kecil dari 0,10). Hal ini mengindikasikan bahwa ukuran perusahaan berpengaruh positif terhadap manajemen laba.

e. Pengaruh Profitabilitas terhadap Manajemen Laba

Pengaruh profitabilitas terhadap manajemen laba dimana variabel profitabilitas diketahui mempunyai koefisien positif dan tidak signifikan terhadap manajemen laba karena besar regresinya 0,127 dan signifikan 0,158 (lebih besar dari 0,05). Hal ini mengindikasikan bahwa profitabilitas tidak berpengaruh terhadap manajemen laba.

\section{Uji Koefisien Regresi Simultan (Uji F)}

Apabila (P-Value) $<0.05$ artinya variabel independen secara simultan mempengaruhi variabel dan bila (P-value) $>0.05$ artinya variabel independen secara similtan tidak mempengaruhi variabel dependen

Hasil uji F dapat dilihat pada tabel berikut:

Table 8: Hasil (Uji F)

ANOVA ${ }^{\mathrm{a}}$

\begin{tabular}{rlrrrrr}
\hline Model & & Sum of Squares & df & Mean Square & F & Sig. \\
\hline \multirow{3}{*}{1} & Regression & 3,209 & 5 & 0,642 & 2,813 & $0,019^{\mathbf{b}}$ \\
& Residual & 29,206 & 128 & 0,228 & & \\
& Total & 32,415 & 133 & & & \\
\hline
\end{tabular}


Nilai signifikan 0,019 < 0,05 maka keputusan Ha diterima artinya auditor switching, KAP big-four, komite audit, ukuran perusahaan, profitabilitas secara bersama-sama berpengaruh terhadap manajemen laba yang terdaftar di BEI periode 2014-2016.

\section{Uji Koefisien Determinasi (Uji $\mathbf{R}^{2}$ )}

Uji koefisien determinasi digunakan untuk mengetahui seberapa jauh kemampuan model dalam menjelaskan variasi variabel dependen (Ghozali, 2011). Nilai $\mathrm{R}^{2}$ yang kecil berarti kemampuan variabel-variabel independen dalam menjelaskan variasi variabel dependen amat terbatas. Nilai yang mendekati 1 (satu) berati variabel-variabel independen memberikan hampir semua informasi yang dibutuhkan untuk memprediksi variasi variabel dependen. Nilai koefisien determinasi yaitu antara 0 dan 1). Berikut hasil pengujian koefisien determinasi

Table 9: Hasil (Uji $\left.\mathbf{R}^{2}\right)$

\begin{tabular}{|c|c|c|c|c|c|}
\hline \multicolumn{6}{|c|}{ Model Summary $^{b}$} \\
\hline Model & $\mathrm{R}$ & R Square & $\begin{array}{l}\text { Adjusted R } \\
\text { Square }\end{array}$ & $\begin{array}{l}\text { Std. Error of the } \\
\text { Estimate }\end{array}$ & Durbin-Watson \\
\hline 1 & $0,315^{\mathrm{a}}$ & 0,099 & 0,064 & 0,478 & 1,365 \\
\hline
\end{tabular}

Berdasarkan tabel di atas diperoleh angka Adjust $\mathrm{R}^{2}$ ( $\mathrm{R}$ square) sebesar 0,064 atau 6,4\%, Nilai koefisien yang dihasilkan menunjukan bahwa variabel independen yang terdiri dari Auditor Switching, KAP Big-Four, Komite Audit, Ukuran Perusahaan dan Profitabilitas mampu menjelaskan kontribusinya terhadap Manajemen Laba sebesar 0,064 atau 6,4\%. Sedangkan sisanya sebesar 93,6\% lagi dijelaskan oleh variabel lain yang tidak digunakan dalam model penelitian ini.

\section{Kesimpulan}

1. Auditor switching tidak berpengaruh dan signifikan terhadap manajemen laba Pada Perusahaan Manufaktur yang terdaftar di BEI tahun 2014-2016.

2. KAP Big-Four berpengaruh positif terhadap manajemen laba Pada Perusahaan Manufaktur yang terdaftar di BEI tahun 2014-2016.

3. Komite Audit berpengaruh positif terhadap manajemen laba Pada Perusahaan Manufaktur yang terdaftar di BEI tahun 2014-2016.

4. Ukuran perusahaan berpengaruh positif terhadap manajemen laba Pada Perusahaan Manufaktur yang terdaftar di BEI tahun 2014-2016.

5. Profitabilitas tidak berpengaruh terhadap manajemen laba Pada Perusahaan Manufaktur yang terdaftar di BEI tahun 2014-2016.

6. Berdasarkan hasil pengujian secara simultan dapat disimpulkan bahwa variabel auditor switching, KAP big-four, Komite audit, ukuran perusahaan, profitabilitas secara simultan (bersama-sama) berpengaruh positif terhadap Manajemen Laba yang terdaftar di Bursa Efek Indonesia tahun 2014-2016. 


\section{DAFTAR PUSTAKA}

[1] Agus Santoso. 2017. "Pengaruh Good Corporate Governance terhadap Nilai Perusahaan dengan Kinerja Keuangan Sebagai Variabel Intervening”. Prosiding Seminar Nasional dan Call For Paper Ekonomi dan Bisni.

[2] Alexandors Ngala Solo Wea dan Dewi Murdiawati. 2015. "Faktor-Faktor Yang Mempengaruhi Auditor Switching Secara Voluntary Pada Perusahaan Manufaktur". Jurnal Bisnis Dan Ekonomi (JBE) vol. 22, No. 2. STIE Perbanas Surabaya.

[3] Alfiani Werdhaningtyas. 2017. "Analisis Faktor-Faktor yang Mempengaruhi Auditor Switching pada Perusahaan yang Tercatat Dibursa Efek Indonesia tahun 2010-2015". Jurnal Akuntansi dan Keuangan Vol. 8 No. 1. Fakultas Ekonomi Universitas Bandar Lampung.

[4] Bastian, Indra. 2014. Sistem Pengendalian Manajemen Sektor Publik. Jakarta : Salemba Empat.

[5] Dendi Purnama. 2017. "Pengaruh Profitabilitas, Laverage, Ukuran Perusahaan, Kepemilikan Institusional dan Kepemilikan Manajerial Terhadap Manajemen Laba”. JRKA Vol.3 Isu 1.University Kuningan.

[6] Edwin Wijaya dan Ni Ketut Rasmini. 2015. " Pengaruh Audit Fee, Opini Going Concern, Financial Disteress, Ukuran Perusahaan, Ukuran KAP Pada Pergantian Auditor”. E-jurnal Akuntansi Universitas Udayana. 11.3 . Bali, Indonesia.

[7] Fahmi, Irham. 2013. Analisis Laporan Keuangan. Bandung : Alfabeta.

[8] Fahmi, Irham. 2015. Manajemen Investasi : Teori dan Soal Jawab. Jakarta : Salemba Empat.

[9] Ghozali, Imam. 2011. Aplikasi Analisis Multivariate dengan Program IBM SPSS 19. Semarang : BP Universitas Diponegoro.

[10] Ghozali, Imam. 2016. Aplikasi Analisis Multivariete dengan Program IBM SPSS 21. Semarang: Badan Penerbit Universitas Diponegoro.

[11] Hafizh Rahdal. 2017. "Pengaruh Ukuran KAP, Ukuran Perusahaan, Arus Kas Bebas, dan Leverage Terhadap Manajemen Laba (studi empiris pada perusahaan makanan dan minuman yang terdaftar di bursa efek indonesia tahun 2012-2014)". JOM Fekon, Vol.4 No.1 . Universitas riau, pekanbaru Indonesia.

[12] Hastuti Widyaningsih. 2017. "Pengarh Corporate Governance Terhadap Manajemen Laba". Jurnal nominal/Volume VI Nomor 2. universitas STIEB BANK Yogyakarta.

[13] Ingrid Panjaitan. 2017. "Pengaruh Ukuran KAP, Return On Assets dan Loan to Deposit Ratio Terhadap Audit Report Lag”. Jurnal Aplikasi Manajemen, Ekonomi dan Bisnis Vol. 1. No. 2. STIM Lasharan Jaya. Universitas 17 Agustus 1945 Jakarta.

[14] Kusumawardhani, Indra. 2012. "Pengaruh Corporate Governance, Struktur Kepemilikan, dan Ukuran Perusahaan terhadap Manajemen Laba". Jurnal Akuntansi dan Sistem Teknologi Informasi Vol. 9, No. 1. Fakultas Ekonomi UPN "Veteran", Yogyakarta.

[15] Luki Arsih Dan Indah Anisykurlillah. 2015. "Pengaruh Opini Going Concern, Ukuran KAP, Dan Profitabilitas Terhadap Auditor Switching". Universitas Negeri Semerang, Indonesia.

[16] Marismiati. 2017. "Pengaruh Corporate Governance Terhadap Manajemen Laba Di Industri Perbankan Inndonesia". Jurnal. Logistik Bisnis, No. 1. Politeknik Pos Indonesia.

[17] Mhd. Hidayat. 2016. " Pengaruh Good Corporate Governance Dan Ukuran Perusahaan Terhadap Manajemen Laba (Studi Empiris Pada Perusahaan LQ45 Yang Terdaftar Di Bursa Efek Indonesia Periode 2011-2014)". JOM Fekon Vol. 3 No. 1. Universitas Riau.

[18] Mohamed Chakib Kolsi Rihab Grassa. 2017. "Did corporate governance mechanisms affect earnings management? Futher Evidence from GCC islamic banks". International Journal of islamic and Middle Eastern finance and Management, Vol. 10 Iss 1 pp, University Fudan.

[19] Purba, Marisi P. 2012. Profesi Akuntan Publik di Indonesia. Yogyakarta : Graha Ilmu.

[20] Rahmawati. 2012. Teori Akuntansi Keuangan. Yogyakarta : Graha Ilmu. 
[21] Rustam, Bambang Rianto. 2013. Manajemen Risiko Perbankan Syariah di Indonesia. Jakarta : Salemba Empat.

[22] Safitri Putri Utami dan Cherrya Dhia Wenny. 2018. "Pengaruh Profitabilitas, Leverage, Ukuran Perusahaan, dan Ukuran KAP Terhadap Praktik Manajemen Laba Pada Perusahaan Industri Yang Terdaftar di Bursa Efek Indonesia”. Jurusan Akuntansi STIE Multi Data Palembang.

[23] Saraswati, Riski, Sulistyo dan Rita Indah Mustikowati. 2016. "Pengaruh Good Corporate Governance dan Financial Distress terhadap Manajemen Laba (Studi Kasus pada Perbankan yang Listing di Bursa Efek Indonesia Periode 2011-2014)”. Journal Riset Mahasiswa xxxxxxx (JRMx) Volume : xx, Nomor : $\quad$ xx. Fakultas Ekonomika dan Bisnis, Universitas Kanjuruhan, Malang.

[24] Subramanyam, K.R. dan John J Wild. 2013. Analisis Laporan Keuangan. Jakarta : Salemba Empat.

[25] Sugiyono. 2012. Memahami Penelitian Kualitatif. Bandung : Alfabeta

[26] Sugiyono. 2013. Metode Penelitian Kuantitatif, Kualitatif, R\&). Bandung : Alfabeta.

[27] Sugiyono. 2014. Metode Penelitian Pendidikan (Pendekatan Kuantitatif, Kualitatif, R\&D). Bandung : Alfabeta.

[28] Sugiyono. 2016. Metode Penelitian (Kuantitatif, Kualitatif, dan R\&D). Bandung : Alfabeta.

[29] Sugiyono. 2016. Metode Penelitian Kuantitatif, Kualitatif, R\&). Bandung : Alfabeta.

[30] Sutedi, Adrian. 2012. Good Corporate Governance. Jakarta : Sinar Grafika.

[31] Vina Kurniaty. 2014. " Pengaruh Pergantian Manajemen, Opini Audit, Financial Distress, Ukuran KAP, Dan Ukuran Perusahaan Klien Terhadap Auditor Switching Pada Perusahaan Real Estate Dan Properti Di Bursa Efek Indonesia". Jom Fekon Vol. 1 No 2. Faculty Of Economic Riau University, Pekanbaru, Indonesia.

[32] Vivi Kumala Oktari. 2018. "pengaruh Ukuran Perusahaan Dan Corporate Governance Terhadap Manajemen Laba Pada Perusahaan Food And Beverage Yang Listing Di Bursa Efek Indonesia". JOM Fisip Vol. 5. Universitas Riau.

[33] Yuka Faradila Dan M. Rizal Yahya. 2016. “ Pengaruh Opini Audit, Financial Distress, Dan Pertumbuhan Perusahaan Klien Terhadap Auditor Switching". Jurnal Ilmiah Mahasiswa Ekonomi Akuntansi (JIMEKA) Vol. 1, No. 1, Universitas Syiah Kuala. 